\title{
An Overview and Approach towards Autism and its Management in Ayurveda
}

\author{
Prashant L Patil* and Pravin W Bonde
}

Department of Kaumarbhritya, Government Ayurved College, Nanded, India

${ }^{*}$ Corresponding author: Prashant L Patil, Department of Kaumarbhritya, Government Ayurveda College, Nanded, India, Tel: 02462 234 026 ; Email: prashantpatil371976@gmail.com

Rec date: November 15, 2017; Acc date: January 08, 2018; Pub date: January 18, 2018

Citation: Patil PL, Bonde PW (2018) An Overview and Approach towards Autism and its Management in Ayurveda. Ped Health Res Vol.3: No.1: 1.

\section{Abstract}

Autism is a complex neurodevelopmental disorder that tremendously impacts the normal functioning of brain, challenging child development particularly in the field of language and communication, social and emotion with presence of unusually strong narrow interest and personal occupation by the repetitive stereotype mannerism.

The disorder that usually becomes evident during the first three years of life. Ayurvedic literatures throws light on etiopathogenesis, presentation along with prophylactic and some specific measures for management of such disorders.

After summarizing scattered references on Autism, it is clear that previous deeds (Poorvajanit karma), (Maithuna charya of parents). The time of conception, the mind of parents, position of parents during coitus, mithyaaharavihara, followed lead to deranged mental growth (Garbhopaghatkar bhava) leads to impaired development of brain and mind (Doshas and Panchamahabhutas) vitiation of kapha and tamoguna as well as vata and rajo guna leads to genetic abnormality beejadusti (Abnomal Garbhinicharya). The mental status of mother plays an important role for both physical and mental development of child. Currently available treatment in conventional system of medicine is Pallative, while in Ayurveda Specific Medhya Rasayana can play a vital role in treatment of autism.

Keywords: Autism; Pervasive developmental disorder; Poorvakarma; Ayurveda; Gabhinicharya; Beejdosha

\section{Introduction}

Autism is also called austim spectrum disorder characterised by involvement of lack of communication, Social interaction and repetitive behaviour. Children with autism might have problem in talking with you or they might not look at you in the eyes when you talk to them [1]. They may have to line up their pencils before they can pay attention, or they may say the same sentence again and again to calm themselves down
[2]. Autism is the prototype disorder for pervasive developmental disorder which is believed to be a complex genetic and neurological disorder that generally lasts throughout a person life. Current statistics shows that autism occur in all racial ethnic and social groups and recently there have been reports of an increase in the number of children receiving a diagnosis of autism or receiving public services for autism [3].

Autistic children however show several savant skills and an excellent rote memory. Those who are educable gain high scores in their scholastic subjects but will not be able to abstract these learnt materials at a functional level [4].

\section{Literature Review}

\section{Diagnostic criteria for autism}

1. Qualitative impairment in social interaction as manifested by at least two of the following.

- Marked impairment in the use of multiple non-verbal behaviours such as eye to eye gaze, facial expression, body gestures and postures to regulate social interaction.

- Failure to develop peer relationships appropriate to developmental level.

- A lack of spontaneous seeking to share enjoyment, interests or achievements with other people.

- Lack of social or emotional reciprocity.

2. Qualitative impairment in communication as manifested by at least one of the following.

- Delay in or total lack of development of spoken language.

- In individual with adequate speech marked impairment in the ability to initiate or sustain conversation with others.

- Repetitive use of language.

3. Restricted repetitive and stereotyped patterns of behaviour, and interest and activities as manifested by at least one of the followings.

- Restricted pattern of interest that is abnormal either in intensity or focus.

- Stereotyped and repetitive motor activity.

4. Delays or abnormal functioning. 
- Social interaction.

- Language as used in social communication [5].

\section{Matruj and pitruj bhavas}

Majja is a matruj bhava important for development of brain (Mastulunga). In Autism it says the role of deranged brain so that the vitiation occurring in matruj bhava leads to the referred problem likewise Atmaj bhav contribute chetana, buddhi, dhriti, smiriti, atmaj bhav vaigunya can cause impairment of function of mind.

In Ayurveda number of causative factor include (poorvakarma) past deeds of life (maithunacharya of parents). Abnormal thoughts and abnormal preconceptional activities leads to these problem, (Garbhapoghatkar bhavas) majja is matruja bhava likewise brain development, retention, thinking is depending on proper development of atmaj bhav, also role of (Garbhinicharya) the environmental and ill thinking nature of mother seriously affect the mental function of the child. (Abnormal dosha and Panchamahabhutas) the predominance of kapha and tamoguna can contribute development of symptoms of children with Autism also predominance of Vata and Raja give rise to emotional, social, communicational, learning problem of children (Beejdushti). It is clear that genetic factor and improper diet during pregnancy leads to autistic behaviour. According to Indian thought Manas is a part of human life chinthyam, vicharya uhyam, dheyam, sankalpam all these are the vishayas of mind.

Mind is essential for acquisition of knowledge through sensory perception experience or learning. The objective of sense is perceived through mind. The mind analyses the nature of the perception received and buddhi determines specific properties of objects.

\section{Etiopathogenesis}

As separate description of Autism has not been described in any of the classics only scattered information about this disease can be found. These causes can be Classified as Nija Nidana (inherited causes) and Agantujanida (acquired causes), out of the nijanidana again may be classified as Sahaja (genetic) Garbhaj (congenital and in pregnancy) and janmottara $[6,7]$.

Sahajanidana (genetic factor): Acharya Sushruta mentioned in his text the state of health and disease are determined by the relative presence of tridosha since the formation of embryo in the womb [8]. Kapha is Tamobhuyistam so that the predominance of kapha and tamo guna can contribute development of vishada, nastikam, adharmasheela, budhinirodha, ajnanam in child, likewise predominance of vata and rajas guna contribute development of dukhabahutwam, tadansheelata dambham and krodha in children. In case of panchamahabhuta akasha is satvabhuyitam, vayu is raja guna predominant and prithvi is tamoguna predominant so that their predominance contributes their qualities in the child. The genetic material is deranged as it leads to beeja dusti which is responsible for basic genetic susceptibility to develop the disease [9].
Matruj pitruj bhavas: Majja is a matrruj bhav important for development of brain (mastullunga). In autism it is says the role of deranged brain so that the vitiation occurring in matruj bhav leads to referred problem likewise atmaj bhav contribute chetana, buddhi, dhriti, smiriti, atmaj bhava vaigunya (vitiation) can cause impairment of function of mind [10].

Garbhaja: The role garbhinicharya the abnormal antenatal condition, mental status of mother, as well as garbhopaghatkar ahar vihara, leads to vatadushti can affect the manas and buddhi takes place in the fifth and sixth month of intrauterine life. The environmental and ill thinking nature of mother prior to these months seriously affect the mental function of the child.

Janmottar: Vataprakopak ahar vihara and khaphaj ksheer also leads to tridosha dushti which further aggravates the hypofunction of dhi, dhriti and smiriti.

Aagantuja: Internal or external injury to the developing brain (shirobhighata) some invisible ill elements (bhutavesh) infections and poisoning leads to tridoshadushti and by vata. There will be manovahastroto sanga (tamas and rajo guna) ultimately may affect the mental and physical development of child $[11,12]$.

\section{Clinical manifestation}

Most children with autism exhibits restricted range of interest, activities, playing behaviour and motor co-ordination abnormalities manifested as stereo types, preservation and lack of social interaction. Autism spectrum disorder are heterogenous in nature, severity and clinical manifestation as well as etiology $[13,14]$.

\section{Management}

In Modern medicine line of treatment include speech therapy, psychotherapy, occupational therapy, behaviour training and, dietary modification. Special education is given to children in their early ages and integrated education is now provided by different educational protocol. Trained mothers play key role in early detection can facilitates well timed stimulation resulting in improved cognitive and language development of these children ensuring early school. Early detection of autism facilitates early intervention identification of abilities, easing of parental anxiety and greater acceptance of child in the community.

\section{Preventive aspects}

\section{They can be further subdivided}

Before conception: In Ayurveda the consanguineous marriages have been prohibited not only by Charaka and Sushruta but biologist have described it. Acharya Bhela clearly mentioned that to prevent the psychological disorders the consanguineous marriages should be avoided. Ayurveda gives prime importance in preconceptionally activities followed by father and mother, the time of conception, position of parents 
during coitus, bad aharvihara leads to mental disorder. Preconception counselling should be taken [15].

Prevention during pregnancy: In the context of Garbhopghatkarbhavas, Acharya Charaka Majja bhava and atmaj bhavas when deranged can cause autism like disorder, also has advised to avoid various faulty dietic regimes, trauma otherwise they can lead to absorption of birth of a child and various psychological disorder e.g. Excessive sleep, an excessive consumption of alcohol by a pregnant woman may deliver with low IQ, poor memory or hyperactive. In the fourth month of pregnancy the fetus heart which is seat of consciousness, becomes active, hence it expresses its desires through the mother this is called Daurhruda. The wishes and desires of daurhrudini if not honoured and gratified may lead to autism [16].

Prevention during delivery: During the second stage of labor Sushruta pointed out that the instruction for bearing down the pains by an Assanaprasava women may lead to psychological abnormality.

Prevention during neonatal period of child: In this respect in Ayurveda Neonatology the absolute first line care of newborn is to facilitate respiration called as Pranpratyagamana (resuscitation) method in the form of cleaning the Mukhasleshma and physical stimuli along with Pranvayu (oxygen) with the help of Krishnakapalikasupa hollow tube with the aim to prevent the birth Asphyxia which is worthy cause of autism.

In Ayurveda Dhee dhairya atmadi vijnam manoaoushodham param. So, for that the main treatment is proper counselling and use specific medhya rasayanas advocated.

\section{Three Types of Chikitsa Play Significant Role in Treating Autism}

\section{Yuktivyapashraya chikitsa}

Different types of internal medication especially Ghrita preparations, medhya drugs and external procedures like Nasya, Dhupanas, Dhoompanas, Shiropichu tailam and oil application to head region to reduce symptom should be adopted.

\section{Daivayapashraya chikitsa}

Ayurveda uses various psychological measures for getting the desired effect of a therapy or condition not responding to treatment. This comprises of chanting of hymn, offerings etc. All this practice acts at the psychological level. As we know that faith is the part and parcel of psychology. It is true that treatment is a play of faith, moreover diseases in Ayurveda is said to be due to deeds of past life and this type of treatment is intended for pacification of such deeds.

\section{Satvavajaya chikitsa}

This include behaviour therapy which help to control senses from harmful objects and controlling temper tantrum. This also include providing awareness to the parents regarding nature of the disease and providing environmental modification for encouraging desired behaviour.

Apart from that medhya and vathara drugs should aim in correction of maladaptive behaviour, reducing hyperactivity, and improvement in area of attention, memory, and motor skills. Medhya drugs acts on Prajnya which correct correction cognitive functions.

\section{Discussion}

\section{Specific treatment}

In Ayurveda various remedies have been described by Acharyas to correct cognitive, adaptive behaviour functions, memory.

Internal medication: Mahapaisachika ghrita, Mahachaitasa ghrita, Mahakalyanaka ghrita, Panchagyvya ghrita these should be selected based on the Manodoshaavastha.

External medication: Himsagaratail, ksherbala tail, shudhhabala tail are found to be effective in this disorder. Procedure should be preferably pichu dharnam and abhyanga, shirodhara and basti can be administered if the subject is older and co-operative. Shirolepa may also be used for immediate relief especially associated with sleep disturbances.

Panchagandha choorna, Kachuradi choorna these may be mixed with any of the above said tail and applied on anterior fontanel.

Sarira abhyanga help to calm down the nervousness in the subjects, tail used may be-Mashadi tail and Lakshadi tail.

Medhya Rasayan-Suvarna with ghrita, vacha and kushta, Arkapushpi ghrita suvarna, vacha with madhu.

Suvarna churna khadira, shwetdurva, and ghrita with madhu.

\section{Conclusion}

Direct references regarding autism like disorder are not available in Ayurveda, after understanding this disorder from Ayurveda aspect the principal of treatment aspect of Manoroga seems to be the most appropriate. Autism is a manifestation having its deep root in beeja dosha activated by favourable environment. The condition requires a long-term intervention and the improvements soon after each course of management. Ayurveda opens a large door in the management of autism and similar condition and shows the ray of hope to those in dark.

\section{Disclosure}

The authors declare no conflicts of interest. 


\section{References}

1. Gillott A, Furniss F, Walter A (2001) Anxiety in high-functioning children with autism. Autism 5: 277-286.

2. Pellicano E, Jeffery L, Burr D, Rhodes G (2007) Abnormal adaptive face-coding mechanisms in children with autism spectrum disorder. Curr Biol 17: 1508-1512.

3. Green VA, Pituch KA, Itchon J, Choi A, O Reilly M, et al. (2006) Internet survey of treatments used by parents of children with autism. Res Dev Disabil 27: 70-84.

4. Happe FG (1995) The role of age and verbal ability in the theory of mind task performance of subjects with autism. Child Dev 66: 843-855.

5. Murray D, Lesser M, Lawson W (2005) Attention, monotropism and the diagnostic criteria for autism. Autism 9:139-156.

6. Belmonte $M K$, Allen $G$, Beckel-Mitchener A, Boulanger LM, Carper RA, et al. (2008) Autism and abnormal development of brain connectivity. J Neurosci 24: 9228-9231.

7. Joshi RR (2004) A biostatistical approach to Ayurveda: Quantifying the tridosha. J Altern Complement Med 10: 879-889.

8. Vyse TJ, Todd JA (1996) Genetic analysis of autoimmune disease. Cell 8: 311-318.
9. Fletcher PC, Happe F, Frith U, Baker SC, Dolan RJ, et al. (1995) Frith $C D$ other minds in the brain: A functional imaging study of "Theory of Mind" in story comprehension. Cognition 57: $109-128$.

10. Shu BC, Lung FW (2005) The effect of support group on the mental health and quality of life for mothers with autistic children. J Intellect Disabil Res 49: 47-53.

11. Happe F (1999) Autism: Cognitive deficit or cognitive style? Trends Cognitive Sci 3: 3216-3222.

12. Rapin I (1991) Autistic children: Diagnosis and clinical features. Pediatrics 87: 751-760.

13. Constantino JN, Gruber CP, Davis S, Hayes S, Passanante N, et al. (2004) The factor structure of autistic traits. J Child Psychol Psychiatry 45: 719-26.

14. Spiker MA, Lin CE, Van Dyke M, Wood JJ (2012) Restricted interests and anxiety in children with autism. Autism 16: 306-320.

15. Leuzzi RA, Scoles KS (1996) Preconception counselling for the primary care physician. Medical Clinics 80: 337-374.

16. Brambilla E, Felloni A, Gagliani M, Malerba A, Garciia-Godoy Fr, et al. (1998) Caries prevention during pregnancy: Results of a 30-month study. J Am Dent 129: 871-877. 